\title{
Geopolitics of Central Asia: Between the Russian Bear and the Chinese Dragon
}

\section{ONDŘEJ HYNEK*1}

${ }^{*}$ Department of Political Science, Faculty of Social Sciences, University of Cyril and Methodius in Trnava, Slovakia

\begin{abstract}
The countries of Central Asia are driven by economic development. However, they are lacking financial resources, and a gap in cooperation among the countries is making the development stage even more problematic. The important geostrategic location is attracting the attention of global superpowers. Russia has been maintaining close ties with the countries since the disintegration of the USSR. Nevertheless, does Russia have enough possibilities and tools to satisfy these states? This paper inquires why the region represents a crucial point from the perspectives of global superpowers. In doing so, the study describes the most likely future of the region and of global actors' involvement. It also outlines who is currently more dominant in the area, or possibly how the influence is divided between the territories. Lastly, the paper shows how the balance of power has changed with China becoming the main actor, or at least one with the highest potential. The process-tracing method and the geopolitical concept are anchoring the paper and shaping the course of the argument.
\end{abstract}

\section{Keywords}

Central Asia, Russia, China, geopolitics, energy

DOI: https://doi.org/10.24132/cejop_2020_4

How to cite: Hynek, O. 2020. "Geopolitics of Central Asia: Between the Russian Bear and the Chinese Dragon.” Central European Journal of Politics 6 (2): 73-93. DOI: 10.24132/cejop_2020_4

\footnotetext{
${ }^{1}$ Address: Ondřej Hynek, M.A., PhD candidate, Department of Political Science, Faculty of Social Sciences, University of Cyril and Methodius in Trnava, Bučianska 4/A, 91701 Trnava, Slovakia. E-mail: ondrejhynek@yahoo.de
} 


\section{Introduction}

Central Asia plays a strategic crossroad of global importance. The region represents a geopolitical area that has a significant impact on global security. With a population of 66 million, it lies at the crossroads of Europe, the Middle East and Asia, and has enormous natural resources, many of which are beginning to be explored. Historically, these advantages have placed it at the heart of tensions between some of the world's most powerful states and contributed to the thorny transboundary security issues. The governments of the Central Asian states have identified several main themes as key security priorities: water security and transboundary water management; energy security; terrorism; and border management. The relevance of the region is coupled due to the abundance of hydrocarbon reserves. Even though these concerns primarily affect the region itself, they have significant consequences for China's and Russian national interests. Central Asia's security issues are closely aligned with their national security priorities. The region is mainly composed by the former Soviets republics that have gained their independence 30 years ago. The countries are striving for the development of the whole societies; nevertheless, the development process is significantly slower, and the countries are dealing with problems that are occurring as they lack the cooperation of the leadership to solve and overcome the arising problems.

The new geostrategic environment thanks to the states' independence provided new space for the international actors on the chessboard in Central Asia, coupled with establishing of the diplomatic affairs between the regional entities and the outer world that are needed for the further development. Moreover, neighbouring China has global ambitions to change the world order and values to which we adhere, and as the part of the Chinese aspiration is the region of Central Asia. Furthermore, the region was historically in the focus of China due to many reasons, for example, the trade nodal and as the territory for rivalry with other powers (Juza 2016; Karabayeva 2019; Baig 2020).

The Soviets legacy rooted in strong connections between the former republics and Russian Federation when the cultural heritage, as well as language, are firmly embedded and thus the countries have been remaining vital for Russian foreign policy (Gusev 2019). Logically, the Russian Federation, thus, represents the main partner for the countries when Russia provides significant support. However, does the support satisfy the beneficiaries, or is there any other actor that could replace Russia in its prominent position? Although the countries have established substantial affairs with the Russian Federation, China is attempting to shatter the leading position within the region due to its geopolitical aspirations which are simultaneously accompanied by geoeconomics. In other words, China is gradually put more focus on the region of Central Asia, mostly because of the Belt Road (Umarov 2020). On the other hand, Russia does not hold its influence because of history only although history plays an inherent factor, it is determined by other factors as well (Gusev 2019). 
This paper introduces Central Asia's geopolitical significance for China's and Russia's foreign policies when the main objective is to expose the current regional geopolitics. The research questions are the following: (1) Does the Russian Federation have the power to maintain its hegemonic position among the countries? (2) Why is the region essential for Russia and China?

\section{Geopolitical perspective}

The main character of geopolitics, Sir Halford Mackinder, stated that Central Asia's geography represents the world's most vital place, marking it as the pivot region of the world's politics. He asserted that command of this "Heartland" subsequently leads to govern of the entire world: "Who rules the Heartland commands the World-Island; Who rules the World-Island commands the world" (Mackinder 1942: 106; more to the current use of the Heartland concept, see Megoran and Sharapova 2013; Herman and Hung 2013). Furthermore, Mackinder claimed that Eurasia contains an advantageous position. Also, the spatial signifies its notability and magnitude due to faster or easier, delivering the goods instead of ocean paths. He pointed out that the region can constitute the economic and military power as it can ascribe the significant control over the territory that means vital trade point (Mackinder 2004).

Currently, the geopolitics are going through a revival period. All the major powers are more or less efficiently extending their sphere of influence. Besides the traditional superpowers, we can see even the local or regional actors who are trying to redesign the power structures. It is easy to attribute Central Asia's vital position to its neighbourhood countries. The five countries of Central Asia; Kazakhstan, the Kyrgyz Republic, Tajikistan, Turkmenistan, and Uzbekistan lay amid Russia to the north, China to the east, Afghanistan and Iran to the south. Equally crucial, the region is ample in natural resources, including dominant oil, gas.

According to Mackinder (2004), Russia can face so-called yellow peril when China would like to amplify its presence and gains in the region what is currently happening. China has to be more active in the region in the last decades because of the natural resources critically needed for Chinese industry. Further, the region is an important trade node as Mackinder stated what attracts China due to their projects, better known as Belt Road Initiative (Herman and Hung 2013; Baig 2020).

We could add inherent factor nowadays, and so the natural gas resources that could not be predicted at the beginning of the $20^{\text {th }}$ century. The natural resources just underline the economic and strategic input of the region into the international relations. The graphic below (Figure 1) shows the inquired region corresponding with Mackinder's perception, where are even visible the borders with Russia and China. To sum up, 
Mackinder argued who controls this area, accumulates the tremendous power in its hands on the chessboard enabling to control the entire world.

Figure 1. Map of Central Asian Countries ${ }^{2}$

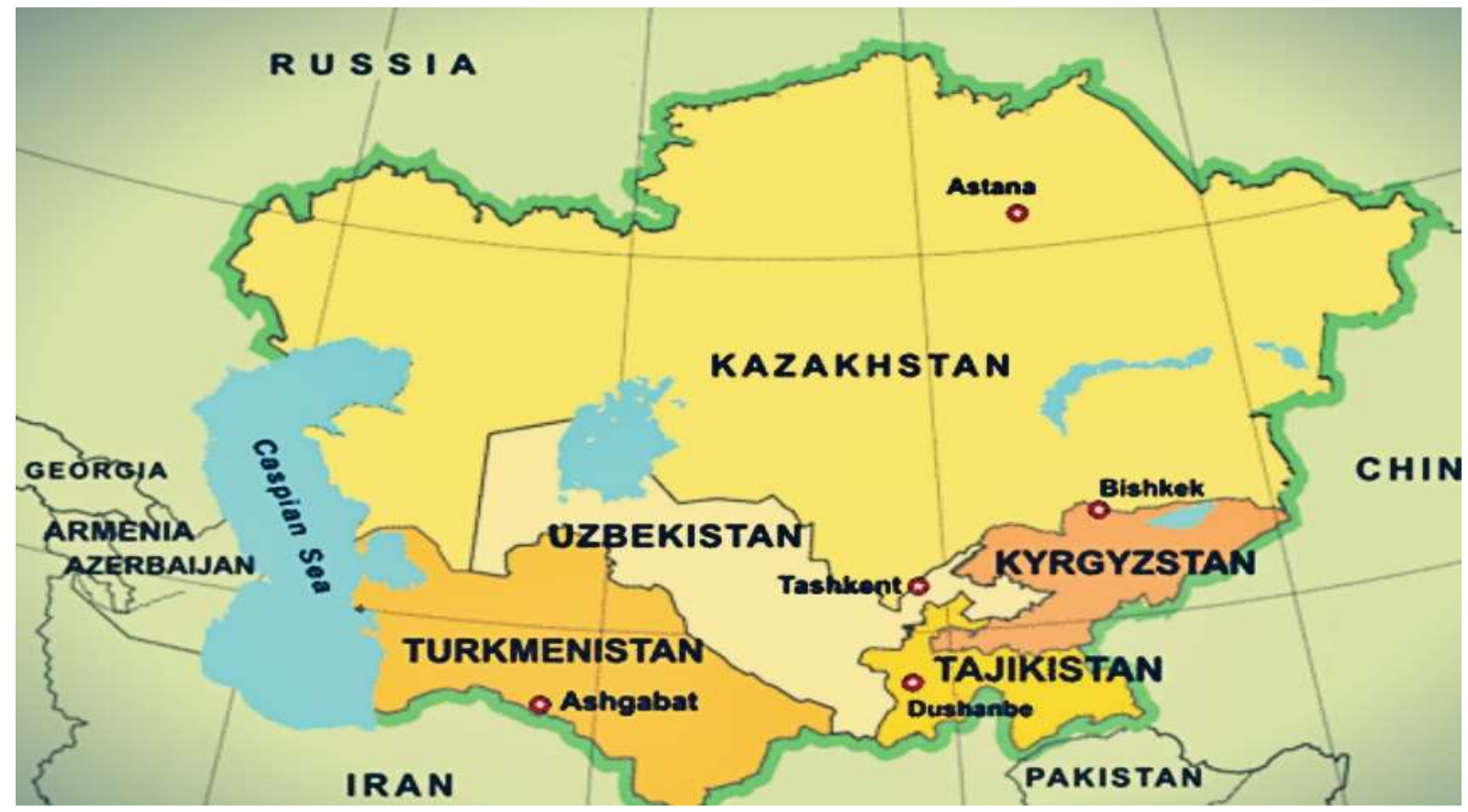

Source: Siddiqui (2018).

\subsection{Conceptualization}

Conceptualization of the presented paper enacts four rigid variables that are the yardsticks and so, physical geography, location, cultural patterns and financial resources. The pattern is chosen according to Scholvin (2016) and his traditional perspective of geopolitics when the author extends the concept with the financial resources as the vital component in the current globalized world.

To begin with the impacted countries, we examine these above-written geopolitical variables. Subsequently, we continue to expose the last variable for Chinese and Russian foreign policy, and how they use it towards the region. Such an approach should be sufficient enough to answer constituted research questions from those we can conclude the study goal.

First, we will mainly aim at the physical geography what seems to be rational as the countries are pushed by two sides simultaneously. However, the physical geography contains a more profound value in the sense of natural resources or shortages of any vital element related to the geographic conditions. Secondly, the location itself might be critical for any purposes, and thus the factor of spatial is inquired too. Crucially, we cannot forget

\footnotetext{
${ }^{2}$ Further referred under the abbreviation “CAR” (Central Asia Region).
} 
on the political-cultural dimension that enables to achieve the goals through policymaking decisions. Lastly, the wherewithal influence, importantly, the outcomes of geopolitical conquering. Here, Luttwak (1998) exemplifies in-depth argumentation about the shift from geopolitics to geoeconomics. Luttwak (1998) argues that the military capabilities are not only existing methods in the conflict. If the military capabilities are comparable, the actors can compete with economic power. With this in mind, the states can enhance their affairs with others in order to weaken someone else. As Luttwak (1998) noted, the trade means became equal to military means because the trade can contain the punishing content, strategic purposes or impose particular attitude/behaviour.

Furthermore, geoeconomics are currently an important tool in foreign policy. Scholvin and Wigell (2018) describe geoeconomics as the strategy of foreign policy in order to secure the geostrategic goals by using economic power. They are, thus, saying the researchers should aim at states as the key subjects in the international arena, and their policies. To conclude, our aim is to examine how financial resources are shaping the region and why the actors are investing the money into the region what corresponds with the research question two.

The Central Asian republics contain certain regional attributes stemming from geopolitics as Scholvin (2016) illustrates the discipline. We, thus, describe the region's significance, assign the geopolitical attributes to the region and its position towards both superpowers, Russia and China. Above that, Russia and China are pumping the financial resources in the region in order to ensure their influence in the region. According to Dave and Kobayashi (2018), commercial ties and trade are the key pillars of China's foreign policy. Therefore, we examine the influence of economic power that ensures the political influence amid the countries. Considering this scheme, we will be able to analyse the whole situation from all angles and subsequently answer both research questions.

\section{Methodology}

The time-framework of presented paper is set up from 1991 until 2020. The year 1991 corresponds with the significance of the year when the Central Asian states gained their independence, and it is the suitable cornerstone that epitomizes the trigger attribute in the process-tracing method scheme (below).

The method is representing the critical component of each research, and the suitable chosen method leads to the favourable and valid results and therefore brings credibility. The process-tracing method appears to be the feasible method that guides the research, accordingly the research goal, to the desired outcome. The process-tracing method operates with three key variables: Trigger, Causal Inferences and Outcome (Collier 2011). Bennett and Checkel (2012) explain the method "as the analysis of the evidence on processes, sequences, and conjunctures of events within a case for either 
developing or testing hypotheses about the causal mechanism that might causally explain the case." (Bennett and Checkel 2012: 7; see Collier 2011; Punton and Welle 2015)

The aim is, thus, to look for the actions, and political decisions that happened or have been happening since 1991 when the countries' statehoods have established. We are inquiring the causal inferences that have been conducting two superpowers, the Russian Federation and China what will conclude in specific outcomes. In the beginning, the outcome box works with the definition "Rivalry between China and Russia" or "China is increasingly active in CAR / Russia is slightly losing its position". However, these statements have to be critically proven by the analysis by the "middlebox", and therefore the outcome can sound differently at the end of the research. The graphic beneath (Figure 2) demonstrates the processing logic. The trigger that constitutes the major powers rivalry over the region is stemming by the Mackinder's theoretical background as well as from the political transition in during the last decade of $20^{\text {th }}$ century.

First, the geographic location itself is appealing for strategic purposes and simultaneously for natural resources reserves what correlates again with the theoretical background. Secondly, the independence of the countries enabled new expansion possibilities in foreign affairs matter how to establish new connections and influence the regional direction.

Figure 2. Illustration of the process-tracing method

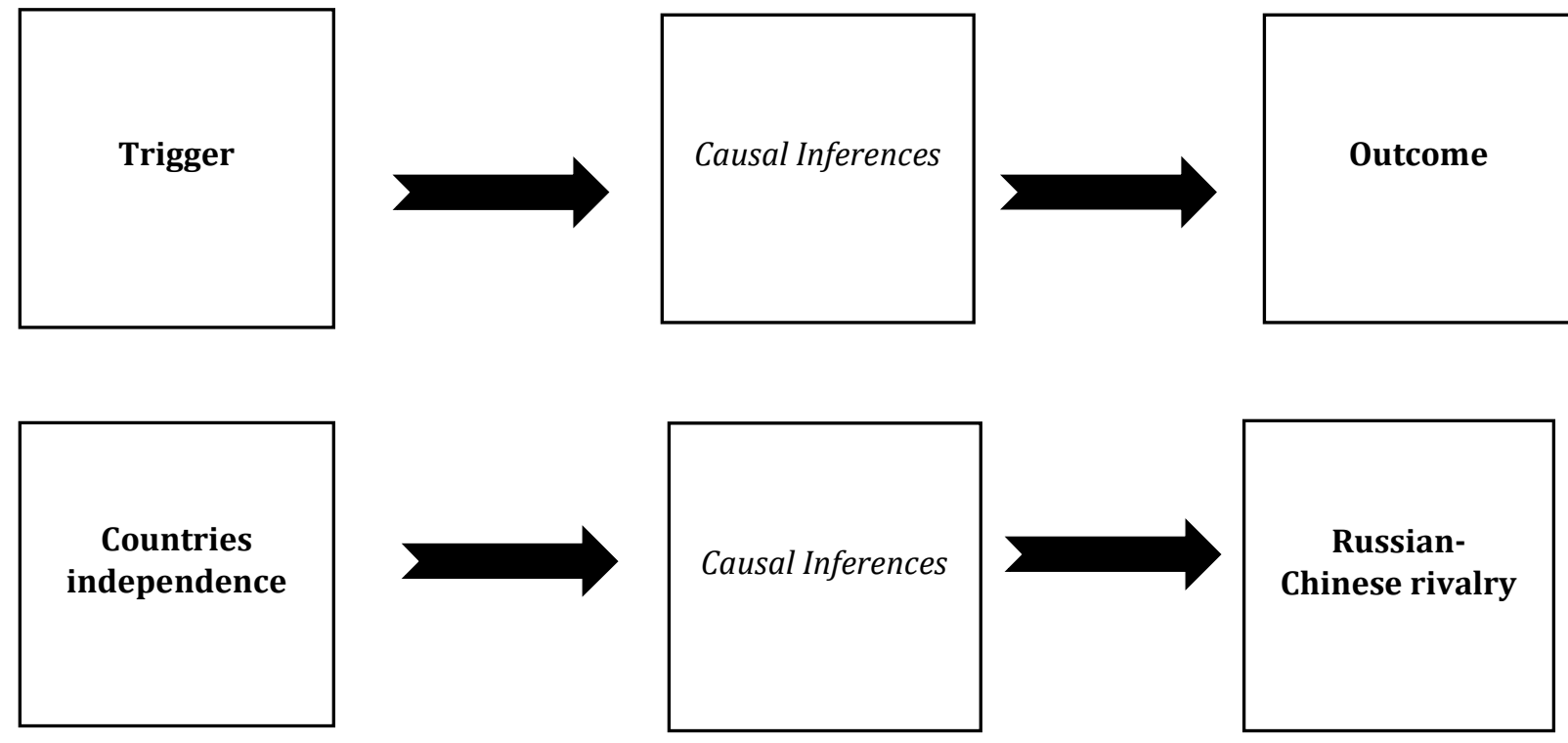

Source: author. 


\section{Results}

\subsection{Regional actors}

The Central Asian region is witnessing a major rebalancing of power. China's rise in Central Asia is because of its broad policy for regional connectivity. Moreover, China is attracted by the Central Asian energy resources, and Chinese enormous financial reserves, which it distributes to Central Asia through commercial investments, loans, the Asian Infrastructure Investment Bank, and several other entities, provide the key advantage for Chinese foreign policy. "Unlike the West, China makes no demands for political reform from Central Asian governments. Unlike Russia, Beijing does not use political pressure to keep the region in its general orientation. The lack of an overt political agenda-other than regional stability, which Beijing believes can be guaranteed through economic development- makes China particularly attractive to local governments" (Stronski and Ng 2018: 9).

The year 1991 constitutes a milestone when the Soviet Empire, in other words, Russia, lost its significance and parts of its territories, including the region of Central Asia. The event meant that Russia has to compete and eventually secure its power in the region repeatedly. Therefore, nearly 30 years ago the states occurred from the long-lasting soviet governance. The disintegration of the USSR brought many challenges, mostly economic matters and the transformation from a planned economy into the market economy (Stark and Ahrens 2012; Dowling and Wignaraja 2006). Simultaneously, democracy became a new vision for the states (Omelicheva 2015; Horák and Šír 2009). The countries are, however, remaining poor accordingly World Bank. It is a diverse region with a mix of upper middle- and low-income countries with paramount strategic importance due to their geographic location and natural resource endowments (World Bank in Central Asia n.d.). The natural resources have boosted the connection between the region and the world economy; nonetheless, the regional cooperation lacks any economic organization, what is more, the cooperation has slowed down (Burunciuc and Izvorski 2019). On the other hand, natural resources could be considered exploiting by the states. As Juza (2016) mentions, the countries balance on the line between bankruptcy and natural resource limits. The previously mentioned factors are representing the trigger in the processtracing as the geostrategic environment changed and provided new possibilities for all possible actors who could step in the region and begin to spread their influence.

The region has several specific aspects regarding physical geography that assign individual dynamics. First, we can divide the ambience among the countries; those who are suitable for agriculture and on those who are amiable on water resources. Kyrgyzstan and Tajikistan get the most rain and thus are associated with water sufficiency when Turkmenistan and Uzbekistan lack water resources (Russell 2018). On the other hand, Turkmenistan and Uzbekistan possess the affluent locations of the gas. The Caspian 
energy resources are the most appealing factor for other players as Russia, China or even the European Union. The international actors are, indeed, aware of the strategic importance to hold access to the gas reserves. Kazakhstan is, on the other hand, aware of the key position of the transition country which possesses a great number of oil reserves.

Turkmenistan has the fourth-largest gas reserves globally, while Kazakhstan has the twelfth-largest oil reserves (Lopour 2015). Tajikistan and the Kyrgyz Republic, nevertheless, are reliant on oil and gas imports from the other Central Asian states to fill energy needs, as they lack the sources and capacities. Soviet-era infrastructure complicates the energy situation. During the Soviet regime, all pipelines infrastructure ran northerly to Russia. After independence, these pipelines adversely limited Central Asia's export possibilities and provided Russia with monopoly control over the sector (Chow and Hendrix 2010). Such a factor enables significant advantage for Russian Federation shaping the regional outcomes. Since the fall of the Soviet Union, the states in the region have set up new oil and gas pipeline paths to diversify into new markets and boost the exports. However, the main obstacle for exporters is geographical conditions as Central Asia is landlocked without direct access to the sea routes. It means that China or Russia are remaining the main players thanks to the geographic measures what limiting the operating environment of foreign policy for Central Asian countries.

The location gives the region unique content. Besides the oil and gas reserves, the region represents particular crossroads of cultures, religions and thus spheres of influence. The importance emphasizes the U.S. deployment of their forces in Kyrgyzstan in order to operate in northern Afghanistan. Also, the actors can perceive the region as the crossroad between these spheres for commercial purposes what could be mentioned even in the adverse connotation, for example, the drugs (Loupor 2015). The risk of spreading the fundamental Islam into the inquired countries could degrade the statehoods for long term (Horák and Souleimanov 2007; Lynch et al. 2016). Since 2001, the risk of radicalization of the local population grew. It is due to the desperate situation in the region, so many people do not see any other possibility than to accept to follow radical groups that offer wherewithal as the solution (Demirjian 2015). The location is, however, more problematic due to the post-soviet legacy that impacts the border management and border declarations because the Kazakhstan and Kyrgyzstan gave a certain number of territories to China and Tajikistan does not have fixed border with China (Juza 2016).

Above-mentioned entails that the states have to tailor their policies in strengthening the international affairs to get the track for financial possibilities for their future projects. Logically, Russia is the main regional partner due to the cultural ties from the USSR reign; however, China is occurring to be the counter-part when has to be outlined that both countries have the access as they share the borders with the region to the local markets and politics. The local governments are aware of the situation and the capabilities of both actors, so they seek for influential balance amid the affairs, because 
without any other local stalwart actor, the one side collaboration could, in the end, thwart the pursuit and end with a dictate from China or Russia (Sridhar 2020).

Generally, the inquired Eurasian space is getting less synoptical than in the last decades, but it emphasizes the theoretical approach from Mackinder and his pivotal arena. It appears that Russia is not the only player in the regional structure anymore; however, China has been engaging in more inert position too what stems from the geographical logic when the region is located exactly between Russia and China.

\subsection{Russia and China in Central Asia: Energy}

The Russian Federation had controlled the gas market in Central Asia for a long time with the particular monopoly position thanks to history linkages. The capacities and gas infrastructure were, already, being built during the time of USSR what puts the Russian gas companies, nowadays, in much favourable position that for instance local companies, Chinese or European. Gazprom (Russian majority state-owned energy corporation), therefore, significantly control the Central Asian pipeline running into Russia although the Central Asian pipeline network is connected to the Russian system in northern Kazakhstan. Also, recently, Russians participate in gas purchasing in Uzbekistan and Turkmenistan, and what is more, the companies like Lukoil and Gazprom are even building the capacities for consequent gas distribution in Kyrgyzstan (Oliphant 2013; Pirani 2019). The Russian involvement tied the Central Asian countries on Russian technology as Russians manage the gas infrastructure.

Furthermore, Russian President Putin was also able to involve Russia into the Central Asian republics' project to construct the pipeline into the European Union. This decision strengthens the Russian position in the region and also towards external rivals. The European Union has been attempting to lessen the dependency on Russian imported gas and the supplement route from the Caspian Sea could eventually match with that particular vision. It entails that the European Union's endeavours are not achieved. The region, thus, remains inherently in the aim of Russian policy decisions as Russia can benefit from the regional natural resource when Russians can provide the technology plus know-how and financial resources. The decision or policy of such content is causing more stable and stalwart position in the regional geopolitics due to anchoring in the key sector of the economy. Such strategy underlines the Mackinder's envisaging about the region as we can see that Russia is attempting to hold the dominant position due to the natural resources to which Mackinder referred. The Russian Federation has the know-how related to gas transportation as well as the financial resources to support the capacities building. Besides that, we cannot forget about the transition aspect that is bringing specific power position. The infrastructure plans as foreign policy mechanisms are giving significant control in Russians' hands. Importantly, the energy sector is a critical component in Russian policies and grand strategies. 
On the other hand, China conducts particular actions that increase its role in the gas sector because China is interested in energy resources as well as Russia (Šír and Horák 2008). Therefore, China is investing in developing the extraction capacities on the coast of the Caspian Sea in Turkmenistan and Kazakhstan, and simultaneously stabilizing the other states by financial possibilities (Juza 2016; Eponychia 2019). Such events are weakening Russia's position in the region and China, due to these events, is becoming step by step more crucial player in the regional politics and partner for the regional countries. With this in mind, the financial resources are a key tool for push ahead of its interests.

Indeed, this is done for logical reasons, and so China can bypass the energy routes from Russia and deliver the energy through the post-soviet republics what will subsequently anchor its geopolitical position. This appears, moreover, inevitable for China itself because China can face to the shortages of electric power and in order to sustain its growth, they have to ensure enough resources and Central Asia signifies the way (Juza 2016). The possible vision of shortages has triggered China for deeper cooperation and spreading its influence into Central Asia in order to meet its energy demands, and therefore this is the particular trigger in the regional relations that should be added into the process-tracing illustration. These foreign strategies increase Chinese influence as the countries have been looking for more partners and to diversify their market, importantly this is not limited to China. China, of course, took this advantage to undermine the Russian hegemonic position in Central Asia. Therefore, we can to observe the action by regional actors too, who are contributing to the regional political mechanisms what ultimately means two big players in the region, instead of one.

Secondly, the ambience is rich in a natural resource that is a vital component for gradual Chinese growth. With this in mind, China has been investing in the name of geoeconomics in the extracting the gas resources in the Caspian Sea in Turkmenistan that is utterly reliant on China, and in Kazakhstan (Juza 2016). Kazakhstan has been already playing the pathfinder role for a long time as the Kazakhstan-China oil pipeline illustrates the very first collaboration among China and the region in the sense of energy security and deals. Crucially, China has been investing vast resources in pipeline infrastructure with Kazakhstan. The first three pipelines of Central Asia-China, which supply China by Central Asian gas, were all completed by 2014 - lines A, B and C. Moreover, we can find another pipeline under construction which should start to operate in 2022 - line D (Bradshaw and Waterworth 2020). They now have been promoted as part of the Belt Road's achievement. China, definitely, benefits from the fall of the Soviet Union when they started to set up the relations with Central Asia, concretely with Kazakhstan, for instance, the railway connection (Stronski and Ng 2018).

Another key fact to remember is that China wanted to extend the energy supplies by Turkmen reserves, and therefore China agreed with Kazakhstan on extending the pipeline. Thus, the pipeline has been constructed into Turkmenistan and running the gas route through Uzbekistan (Golovnina 2007). These efforts subsequently continued; thus, 
nowadays we might find three fully operable pipelines and one waiting to be open in 2022 (Bradshaw and Waterworth 2020). These projects diversify the gas delivery possibilities because, until that time, the Russian companies engage the monopoly role; thus, the role of Russia diminished by the constructions. Oliphants (2013) allays that the Chinese entry in the market profoundly change the balance in the market with natural resources, although Russia remains the major player supplemented by China only. However, China recently bought stocks in Russian companies that are operating in the gas market in Central Asia, concretely in Rosneft (Stronski and Ng 2018).

These diplomatic affairs are circulating around the gas resources. We can see that the mutual interest of any external actor is the gas. Nonetheless, no actor is able to maintain a strong relationship in order to keep total control. The regional countries are, of course, aware of this interest, and can move on the brink because they know that another superpower is waiting behind the door. Moreover, China needs gas for a different reason than Russia. China needs to supply its industry in order to maintain its economic growth. On the other hand, Russia has a monopoly over the gas sector and benefits from it on energy markets historically.

\subsection{Russia and China in Central Asia: Political-economic engagement}

Russia has been historically the most influential actor in the Central Asian republics when the countries were connected through the shared past of the Soviet Union and under the patronage from Moscow. The historical roots are particular vestige. On the other hand, China was for a long-time sleepy giant in the region bordering from the north with Kazakhstan, Kyrgyzstan and Tajikistan. However, this is no longer a valid statement since China has been increasing its activities towards the regional actors what threatens the Russian hegemony. Contradictory to Russia, China does not have a post-colonial legacy like Russia in the region. The major Chinese interests in Central Asian states are the energy supplies as well as the economic potential. China can significantly benefit from the geographical position since the borders with three countries.

Russia was always aligned predominantly as the European power, so they had to start orient also on the east in order to strengthen and improve its own territories and ensuring the influence in the post-soviet republics. However, other world superpowers were pushing on the region when the USA was using the region for its operations against the Taliban, and China has been sneaking around due to the economic possibilities. Russia, thus, had to engage an appropriate approach towards the region in order not to lose the influence.

The above-mentioned can be epitomized by Russian incentives when the officials have triggered the establishment of the organizations between the actors. Russia, therefore, leads multinational institutions of the Collective Security Treaty Organization 
and Eurasian Economic Union. These incentives aim, particularly at trade and security challenges. Russia sees the region through security, mainly (Gusev 2019). Nevertheless, the key partners for Russia remain Kazakhstan, Kyrgyzstan and Tajikistan where the Russian Federation has the most reliable position.

The mutual history impacts the region as well. The more than 70 years of Moscow reign left the apparent marks that indicate the Russian cultural-political influence. Economic ties are being elaborated further below in the text; however, it was a key mechanism of how to stay incorporated in the region. It was accompanied, and still is by the elites that were growing during the Soviet period, and thus they are oriented on Moscow (Siddiqui 2018; Oliphant 2013). Within the media, the language plays a strong mark in the sense of particular identity. Therefore, language appears as the main cultural component that enables the smoother flow of communication and understanding. We can still observe the legacy in lacking strong religion bases in the Central Asian countries. Importantly, we do not spectate religious clashes or insurgencies. With this in mind, we have to dig a bit into history, when during USSR, the religious groups were punished and persecuting. Therefore, we can assume that the fundamentalists' roots and terrorist cells are no hooked up in Central Asia so steadily. Moreover, the Russian Federation was not engaged in any war that could be labelled as a religious war, and so the Muslim majority from the post-soviet republics do not feel any hate or anger. The affairs can be underlined by the non-visa access among the countries and Russia, except Turkmenistan.

Such a manner of relations, subsequently, tie the people up, and therefore on both sides, there are massive enclaves of either Russians or citizens from five Central Asian republics that are living in the Russian Federation or in Central Asian states. More specifically, we do speak about four million legal migrants in Russia (Oliphant 2013). Considering the legal workers, we have to add seasonal manpower that enters the labour force annually. This procedure is a win-win situation for the Russian Federation. Saying this, we have to keep in mind the Russian demographic challenges (Oliphant 2013). The workers from five Asian republics gain the vital economic income that is seemingly crucial for workers from countries where high unemployment is prevailing. ${ }^{3}$ On the other hand, the post-soviet legacy can be perceived as the colonialism burden in developing and strengthening the affairs that could be outlined by continency of some countries to participate in organizations where Russia engages the leading position. This approach is utterly different that on China's side, which will be mentioned further in the text.

Besides the cultural factors (language, media, etc.), the post-soviet influence stems from the economic-political cooperation, more precisely said by Russian aid which accumulated to $37 \$$ billion between 2013 and 2016 with significant debt forgiveness by Russia (Dubnov 2018). Even though Russia does not control the territories anymore, it maintains the influence through economic help and common history as the tool of soft

\footnotetext{
${ }^{3}$ For example: $11 \%$ in Turkmenistan in 2020 according to World Bank.
} 
power. Russia has been investing dramatically since Putin is in the presidential office after the consolidation of the internal Russian Federation affairs. Nevertheless, the Russian Federation has been facing economic troubles in the last decade what deteriorates the relations with the Central Asian countries.

Despite the fact that Russia traditionally has been Central Asia's main trading partner the trading ties between Russia and the regional partners have atrophied in the last decade. Russia's 2016 trade volume with the Central Asian countries accumulated to $\$ 18.6$ billion. In comparison to China's $\$ 30$ billion number for the same observed period. Russia has been facing economic problems since 2014, which have accelerated its weakening role amid the region (Stronski and $\mathrm{Ng}$ 2018). The economic problems result in declining Russia's position as the country is not able to maintain the mechanisms ensuring its dominant engagement.

Similarly to activities and organizations where is embed Russia, China has launched "its" institutional framework to reach other actors and incorporate them under one shelter. Shanghai Cooperation Organization ${ }^{4}$ (SCO) illustrates an influential regional cooperation unit that includes all-powerful actors in Asia; thus, including China, Russia, Pakistan and India. The states in Central Asia are, indeed, the members too, except Turkmenistan which holds the guest attendance badge. Someone could argue that the Chinese role is limited due to Russian or Indian membership, coupled with the fact that both states, Russia and China are the leading and establishing countries. By contrast, the name signifies the Chinese role as well as the headquarter, which is based in China. Considering these factors, we should add the financial potential of China in comparison to Russia. On the other hand, China's goal is to maintain security within the region in order to receive what China critically needs: the access into the region in order to develop the ambitious plan of Belt Road, and natural resources what corresponds with the theoretical perspective of Mackinder's Heartland.

To continue with the Chinese interest and simultaneously with SCO, Juza (2016) profess that the organization could create the rout Peking-Nur Sultan-Moscow-Berlin what would accelerate the trade. With this in mind, we should consider the Chinese aim in Central Asia as the essential territory for new Belt Road Initiative. First, China has inherently boosted trade and investments in the last decades. This interest is constituted by the vision of the Belt Road Initiative. As has been mentioned and is even rooted in the theoretical framework, the region contains the crossroad factor, and therefore China could underlying use the territories for the initiative. The Asian Development Bank, under enormous Chinese supervision and influence, has detected six ways when two of them are counting with Central Asia. Yet China continues to construct the transportation routes

\footnotetext{
${ }^{4}$ Eurasian political, security, economic alliance established by China, Russia and Central Asian countries in 2001. More information: http://eng.sectsco.org/
} 
throughout the region with a concrete plan to connect them with Europe what supposed to be the final destination of the Belt Road Initiative.

Chinese motivation is clear also, according to Stronski and $\mathrm{Ng}$ (2018), when they warn about the Chinese aims. China is investing in the region in order to benefit, and Chinese officials follow only their national interests. Generally, the investments and loans are released under specific conditions as the declaration of one China, the beneficial countries have to use the Chinese technology exclusively, and the countries have to use the Chinse workforce (Mattlin and Nojonen 2011; Stronski and Ng 2018). This does not correspond with the vision of sustainable development. Moreover, this is the different policy than Russia applies, where the relations are beneficial for both parties.

First, China's attitude won't create new jobs for locals. Secondly, China receives political support through political declarations. Thirdly, the countries will rely on Chinese technology and management even in the future. The issue is, the countries do not have any other option because Russia does not have the financial resources to build the infrastructure. Someone can argue with Western actors; nonetheless, on the contrary to China, the European Union demands the adherence to western political and cultural values (Stronski and Ng 2018). These processes open the door into the regional policy, and the actors afford China to engage the vital position in the structures. Without a doubt, the foreign policy based on strong economic incentives for Central Asia is successful.

With this in mind, China has different foreign policy towards the region than the Russian Federation. Russian foreign policy is based on cultural legacy and historical ties accompanied by financial aid, and control over the energy infrastructure. On the other hand, China concentrates on stabilizing the countries through economic incentives, not military or security tools. The second goal in Central Asia is to secure the external markets for Chinese companies active in construction and infrastructure development, which is outlined already in the previous paragraph. Although Russian companies want to bid in infrastructure plans in Central Asia, the field is crowded by cheaper actors, including China.

Another crucial point to remember is, Russia offers military education and provides its capacities and capabilities by training for the local officers, and executing the joint-military drills (Gusev 2019). Beyond that, Russia boosted the Kazakhstan defence forces modernization process and built the military bases in Tajikistan and Kyrgyzstan, and these activities underline the security aspect of the Russian presence in the region what is without any doubts connected with the financial pillar of the cooperation.

Nevertheless, Russia has the financial problems which retard even the security cooperation, for example during the year 2016; the Russian military has periodically been unable to pay its local staff at its base in Tajikistan, even though the base serves as a strategic camp in Russia's defence strategy against regional threats. That same year, Moscow pledged over $\$ 1$ billion in security assistance to Dushanbe and promised to increase its troop presence in the country by 2,000 soldiers, but they were not able to 
fulfil the promise (Stronski and Ng 2018). Similar events, scenarios weaken Russia's position in the region, and enable the entry of other actors, in this case, China.

Similar cooperation is visible in Chinese foreign policy. Security plays an important factor in Chinese behaviour towards the region. Afghanistan exemplifies the peril of radical Islamists groups where the spillover effect into other countries could happen. Considering the threat, we should keep in mind that the former Soviet republics faced the particular vacuum of the identities after USSR disintegration. They found themselves in the position they did not know; moreover, the radical beliefs were providing certain, however unlogical, outcomes. China, therefore, as Russia wanted to stabilize the region and build up the connections due to security reasons in order to create a so-called buffer zone (Umarov 2020). With this in mind, the provinces at the border with regional countries are occupied dominantly by Muslim population and ensuring the calm affairs in these territories appears to be crucial as we can see geographically below in Afghanistan. This could be demonstrated by the Chinese military camps in Tajikistan nearby the Afghan border. Since 2014, the western coalition has been withdrawing the forces from Afghanistan, when during the year 2021 all US forces should be pulled back, so China could eventually engage the position of the regional watchdog. Even though there is no clear picture of the Chinese mission or mutual Tajik and Chinese military tasks, it epitomizes specific influence possible new Chinese role in regional dynamics (Shih 2019). Herein, we should grasp that this attitude can be hardly rationally taken for two conflicting reasons.

First, the countries under SCO agreed by signing the agreement on a reduction of the military forces in the border areas simultaneously with mutual trust in the forces who remain in the border territories (Laumulin 2006). Why then Chinese bulwark in Tajikistan is needed remains mysterious. Someone could argue that the military outpost could signify the military cooperation among the countries, but why would it be so concealed? We rather suggest that it is a logical move on chessboard into the "heart" of the former Soviet republics since USA army left the location and Russia has a longer distance to get there, and therefore face more complicated geographical path to get there. Similarly speaks also Shih (2019) who believes that this step is perfectly calculated by Chinese troops when there is no official announcement, and hereby the content of the mission is significantly uncertain.

Moreover, the SCO provides precise control over the military, coupled with military equipment sales because the countries have become reliant on the Chinese industry. Similarly, as the northern neighbour, China has been providing military training for the officers from the Central Asian states what means the particular bids among the actors. However, Chinese strategy is visible even here when Chinese institutions provide more than thousands of places for military personnel from Kazakhstan, and only tens for military personnel from Kyrgyzstan (Stronski and Ng 2018). 
Generally, Russia is historically the key actor in the region with lower involvement during the last decade of the last century when the domestic issues were critical in the Russian Federation. Notwithstanding, Russia has returned in the region thanks to Putin at the beginning of the new millennium, and has continued to develop and establish firm channels among the states and Russia. However, the Russian position is shattering in last years due to several reasons (Pirani 2019). First, the significant involvement of China in the Central Asian affairs is shaping the gas market dominantly, where the China is the top importer already (Pirani 2019), and secondly China thanks to its economic power is anchoring in the region and enacting the strong relations what could subsequently lead to Russian loss of the primary position.

Additionally, Chinese production has become worldwide appealing thanks to the price attractivity, so for less financially strong countries as those located in Central Asia, it can be a stalwart incentive for business. The trade figure demonstrates Chinese regional interest that accumulates to 40 billion dollars and has the tendency to ascend when the annual trade turnover between China and Kazakhstan exceeds 20 billion U.S. dollars, and China reinforced its position as the main economic partner in the region (Oliphant 2013; Kobayashi and Dave 2018; Kangas 2020). The commercial relations put China in position without the region can barely move forward when China toppled Russia from the top economic partner to the second position (Umarov 2020).

China, similarly to Russia, is active on the armour market selling the equipment to Central Asian countries. Such an activity entails that China wants to determine its security role when until now has been seen more as the economic one. If China strikes back at U.S. or Indian efforts in Asia, we could perceive the Central Asian region as the strikes against the Russian position. This underlines Tsz Yan (2019) who asserts that the Chinese technology is much further than Russian as well as modern, and therefore the purchase from the impacted countries is growing. Coupled with the previous statement, we should consider the following countries' bid and eventual debt to China when the countries lack the financial resources. Thus, the countries should adopt a similar policy as Turkmenistan, which will recoup or repay the army purchase by such vital gas for China (Tsz Yan 2019). Umarov (2020), continuously, emphasized the awareness of the influential Chinese ascendency among the countries, and so they are trying to counterbalance the positions between the Russian Federation and China.

\section{Conclusion}

The Central Asian region is essential for both Russia and China due to its natural resources, coupled with trade nodal that representing the gateway to Europe, or similarly in other direction the gateway to Asia. Russia can benefit from its control as the state involved in both continents, and as the enormous player on the gas market. On the other 
hand, China needs to accede the European market in a faster way, and the Belt Road project appears to be attractive for the trade accelerator. Moreover, the country must find how to ensure a sufficient supply of fossil fuels for its rapidly growing economy.

Herein, we can claim that the Mackinder thoughts were in its rudiment correct with slight differences that he could not know, but generally the region still represents critical nodal as Mackinder said and predicted. Both players see the region through the economics lens that can subsequently ascribe the leading position, not on the regional level only. It corresponds even with the more stalwart position of the economy in current international affairs that became equal to military capabilities. We can observe, indeed, within the provided study case, the rivalry without weapons which are masked under financial resources. However, it does not conclude in declining the military ultimately, as we can see even the military attempts in the creation of an inert position in the region.

Another key point to remember is the location of Uzbekistan. Uzbekistan is the only state borders with all other Central Asian countries and simultaneously does not border with China and Russia, which therefore emphasizes its position in the regional geopolitics. Uzbekistan appears to be the critical location, country for ultimate influence in the region because the actor represents the key nodal in the regional crossroad (Weitz 2014). Nevertheless, nor Russia or China are able to tie up more intimate affairs with Uzbekistan in order to secure its dominant position in the region.

"While Beijing's soft power is growing in Central Asia, it still cannot compete with Russia's media presence in the region or the fact that Russian universities, particularly those in Siberia, remain more popular than Chinese ones, although the number of Central Asian students studying in Chinese universities-often with hefty stipends from the Chinese government-is on the rise" (Stronski and Ng 2018: 9; Latief and Lefen 2018). Therefore, further, development can have three different scenarios. First, Russia will remain the primary partner for the region thanks to its deep roots, for example, in the gas sector and cultural heritage. China would, in this case, play a secondary role to satisfy its needs in a limited way, or in a sufficient way without political dominance. This is likely the preferable scenario. The experienced observers assert that the Sino-Russian rivalry is ongoing in Central Asia, although the states mask it beneath "cooperation" (Kaczmarski 2019). Secondly, China will topple Russia from the "regional throne" thanks to economic power. However, there will be an enormous and exciting contest over the gas industry and pipelines. Such a scenario can be barely to be considered as an outcome in the near future. China lacks such a political power network to amplifies its own position. Thirdly, Russia and China will constitute an equal position with sharing the competencies and benefits. This would be, however, only a temporary position because nor Russia or China want to have an equal partner in the long-term horizon.

However, we should not neglect the interests of the entities that constitute the region and are involved in dynamics. The goal should be to ensure the sustainable political, economic, and socio-cultural development, which cannot be realized without the 
necessary stage of functional participation and mutual cooperation in the process underway in the region. Herein should be emphasized, the regional political elites mostly see China's growing presence in the region as the stabilizing factor. They are convinced that Chinese investment in infrastructure will help diversify their economies and speed up the broader economic development (Stronski and Ng, 2018). Also, the deeper connection between the regional states could significantly slow down, or even decrease the degree of political influence emerging from Russia or China.

The relations provide the possibility for further research, especially the impact of the investment projects as well as how the relations will vary in following years. The economic and energy relations will be the main topics in upcoming years. With this in mind, it would be desirably to complete the methods by any economic methods or deeper economic insight as the process-tracing method solely cannot absorb the situation holistically.

\section{References}

Baig, M.A. 2020. "Why the rising China needs alliances." Asian Journal of Comparative Politics 20 (2): 1-20. https://doi.org/10.1177/2057891120965712

Bennett, A. and Checkel, J. 2014. "Process tracing: from philosophical roots to best practices." In: A. Bennett and J. Checkel (eds.). Process Tracing: from Metaphor to Analytic Tool. Cambridge: Cambridge University Press, 3-37. https://doi.org/10.1017/CB09781139858472

Bradshaw, M. and Waterworth, A. 2020. "China's dash for gas: local challenges and global consequences." $\begin{array}{llllll}\text { Eurasian Geography } & \text { End }\end{array}$ https://doi.org/10.1080/15387216.2020.1716819

Burunciuc, L. and Izvorski I. 2019. Encouraging transformation in Central Asia. Washington DC: Brookings.

Collier, D. 2011. "Understanding process tracing." Political Science and Politics 44 (4): 823-830. https://doi.org/10.1017/S1049096511001429

Dave, B. and Kobayashi, Y. 2018. China's silk road economic belt initiative in Central Asia: economic and security implications. Darmstadt: Springer-Verlag. https://doi.org/10.1007/s10308-018-0513-x

Demirjian, K. 2015. "How Russia's Labor Migration Policy Is Fueling the Islamic State." The Washington Post. 11. July. [online]. [cit. 3. 1. 2021]. Available at: https://www.washingtonpost.com/world/ asia_pacific/how-russias-labor-migration-policy-isfueling-the-islamic-state/2015/07/08/15b9300e1141-11e5-a0fe-dccfea4653ee_story.html.

Dowling, M. and Wignaraja, G. 2006. Central Asia after Fifteen Years of Transition: Growth, Regional Cooperation, and Policy Choices. Manila: Asian Development Bank. [online]. [cit. 12. 9. 2020]. Available at: https://www.adb.org/sites/default/files/publication/28460/wp03-cars.pdf

Dubnov, A. (2018). Reflecting on a Quarter Century of Russia's Relations with Central Asia. Washington: Carnegie Endowment for International Peace. [online]. [cit. 23. 1. 2021] Available at: 
https://carnegieendowment.org/2018/04/19/reflecting-on-quarter-century-of-russia-s-relationswith-central-asia-pub-76117

Egorycheva, E. 2019. “Central Asia as an area of China's and Russia's interests." RUDN Journal of Economics 27 (4): 732-742. https://doi.org/10.22363/2313-2329-2019-27-4-732-742

Golovnina, M. 2007. "Kazakhstan, China agree to press ahead with pipeline." Reuters. 8. November. [online]. [cit. 12. 9. 2020]. Available at: https://uk.reuters.com/article/oilRpt/idUKL0888292120071108 Government of the Republic of Kazakhstan. 2007. Kazakhstan, Russia and Turkmenistan agree to renovate the Caspian gas pipeline. Kazakhstan: Government of the Republic of Kazakhstan. [online]. [cit. 19. 9. 2020]. Available at: https://web.archive.org/web/20100309222310/http://en.government.kz/site/news/052007/16

Gusev, L. 2019. The importance of Central Asia for Russian's foreign policy. Milan: Italian Institute for International Political Studies.

Herman, F. and Hung, M. 2013. "China in Central Asia. Harmonizing Mackinder's Heartland." Education About Asia 18 (3): 24-28.

Horák, S. and Šír, J. 2009. Dismantling Totalitarianism? Turkmenistan under Berdymuhammedov. Washington/Stockholm: Central Asia and The Caucasus Institute - Silk Road Studies Program.

Horák, S. and Souleimanov, E. 2007. "Islam, Islamismus und Terrorismus im Nordkaukasus und in Zentralasien - eine kritische Bewertung." In: U. Schlichting (ed.). OSZE Jahrbuch 2006. Hamburg: Nomos Verlaggesellschaft, 297-314. https://doi.org/10.5771/9783845205779-297

Juza, P. 2016. "Stredná Ázia a Čína - problémy politiky, bezpečnosti a možné geopolitické dosledky." Studia Politica Slovaca 1 (1): 34-55. https://doi.org/10.31577/SPS.2019-1.3

Kaczmarski, M. 2019. "Russia-China relations in Central Asia: Why is there a surprising absence of rivalry." The Asan Forum 8 (6) [online]. [cit. 25. 9. 2020]. Available at: http://www.theasanforum.org/russiachina-relations-in-central-asia-why-is-there-a-surprising-absence-of-rivalry/

Karabayeva, A. 2019. "Leaders, ideas, and norm diffusion in Central Asia and beyond." Asian Journal of Comparative Politics 20 (2): 1-20. https://doi.org/10.1177/2057891119887813

Latief, R. and Lefen, L. 2018. "Analysis of Chinese Government Scholarship for International Students Using Analytical Hierarchy Process." Sustainability 10 (7): 2112. https://doi.org/10.3390/su10072112

Laumulin, M. 2006. The Shangai Cooperation Organization as "Geopolitical Bluff?" A view from Astana. Paris: IFRI.

Lopour, J. 2015. Geopolitics at the World's Pivot: Exploring Central Asia's security challenges. Waterloo: CIGI. Luttwak, E. 1998. "From Geopolitics to Geoeconomics: Logic of Conflict, Grammar of Commerce." In: G. Tuathail and S. Dalby (eds.). The Geopolitics Reader. London: Routledge, 125-130.

Lynch T. et al. 2016. The Return of Foreign Fighters to Central Asia: Implications for U.S. Counterterrorism Policy. Institute for National Strategic Studies Strategic Perspectives. Washington: National Defens eUniversity Press.

Mackinder, H. 1942. Democratic Ideals and Reality. London: Constable and Company.

Mackinder, H. 2004. “The geographical pivot of history (1904).” The Geographical Journal 170 (4): 298-321. https://doi.org/10.1111/j.0016-7398.2004.00132.x 
Mattlin, M.A. and Nojonen, M. 2011. "Conditionality in Chinese Bilateral Lending." BOFIT Discussion Paper 14. http://dx.doi.org/10.2139/ssrn.1868792

Megoran, N., and Sharapova, S. 2013. Central Asia in international relations: the legacies of Halford Mackinder. New York: Columbia University https://doi.org/10.1093/acprof:oso/9780199327973.001.0001

Omelicheva, M. 2015. Democracy in Central Asia: Competing Perspectives and Alternative Strategies. Lexington: University Press of Kentucky. https://doi.org/10.5810/kentucky/9780813160689.001.0001

Oliphant, C. 2013. Russia's role and interests in Central Asia. London: Saferworld.

Punton, M. and Welle, K. 2015. Applying process tracing in five steps. Brighton: Centre for Development Impact.

Russel, M. 2018. Water in Central Asia: An increasingly scarce resource. Brussels: European Union. [online]. [29. 2020]. Available at: https://www.europarl.europa.eu/RegData/etudes/BRIE/2018/625181/EPRS_BRI(2018)625181_EN. pdf

Scholvin, S. 2016. Geopolitics an overview of concepts and empirical examples from international relations. Helsinky: FIIA.

Scholvin, S. and Wigell, M. 2018. Geo-economics as Concept and Practice in International Relations. Helsinki: FIIA.

Shih, G. 2019. "In Central Asia's forbidding highlands, a quiet newcomer: Chinese troops.” Washington Post. 19. February. [online]. [29. 9. 2020]. Available at: https://www.washingtonpost.com/world/asia_pacific/in-central-asias-forbidding-highlands-a-quietnewcomer-chinese-troops/2019/02/18/78d4a8d0-1e62-11e9-a759-2b8541bbbe20_story.html

Silk Road Briefing. 2020. “Coronavirus update in the Caucasus \& Central Asia.” Silk Road Briefing. 11. June 2020. [online]. [cit. 20. 9. 2020]. Available at: https://www.silkroadbriefing.com/news/2020/03/19/coronavirus-update-caucasus-central-asia/ Siddiqui, A. 2018. Natura Resources of Central Asia and Politics of Major Powers. Islamabad: PKKH. [online]. [25. 1. 2021]. Available at: https://www.pakistankakhudahafiz.com/natural-resources-central-asiapolitics-major-powers/

Sridhar, V. 2020. "Sino- Russian economic cooperation in Central Asia is not what it seems to be." The Diplomat. 23. September. [online]. [cit. 2. 10. 2020]. Available at: https://thediplomat.com/2020/09/sino-russian-economic-cooperation-in-central-asia-is-not-what-itseems-to-be/

Stark, M. and Ahrens, J. 2012. Economic reform and institutional change in Central Asia: Towards a new model of the development state? Göttingen: PFH.

Stronski, P. and Ng, N. 2018. Cooperation and Competition. Russia and China in Central Asia, the Russian Far East, and the Arctic. Washington: Carnegie Endowment for International Peace.

Šír, J. and Horák, S. 2008. "China as an Emerging Superpower in Central Asia: The view from Ashkhabad.” China and Eurasia Forum Quarterly 6 (2): 75-88. 
Tsz Yan, Y. 2019. “What drives Chinese army sales in Central Asia." The Diplomat. 11. September. [online]. [cit. 29.9.2020]. Available at: https://thediplomat.com/2019/09/what-drives-chinese-arms-sales-incentral-asia/

Umarov, T. n.d. China Looms Large in Central Asia. Moscow: Carnegie Moscow Center. [online]. [cit. 30. 9. 2020]. Available at: https://carnegie.ru/commentary/81402

Weitz, R. 2014. Uzbekistan's National Security Strategy: Threat and Response. Barcelona/Washington, D.C.: Uzbekistan Initiative. [online]. [cit. 29. 9. 2020] Available at: https://centralasiaprogram.org/wpcontent/uploads/2014/07/UI-papers-12-Richard-Weitz.pdf

World Bank. N.d. World Bank in Central Asia. Washington DC: World Bank. [online]. [cit. 28. 9. 2020]. Available at: https://www.worldbank.org/en/region/eca/brief/central-asia 